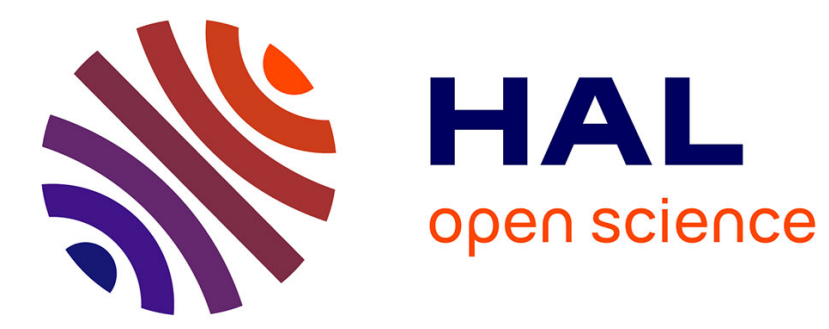

\title{
SHORT RANGE ORDER IN SUPERIONIC CONDUCTORS
}

\author{
J. Boilot, A. Kahn, J. Thery, G. Collin, R. Comes
}

\section{To cite this version:}

J. Boilot, A. Kahn, J. Thery, G. Collin, R. Comes. SHORT RANGE ORDER IN SUPERIONIC CONDUCTORS. Journal de Physique Colloques, 1977, 38 (C7), pp.C7-145-C7-150. 10.1051/jphyscol:1977727 . jpa-00217228

\section{HAL Id: jpa-00217228 https://hal.science/jpa-00217228}

Submitted on 1 Jan 1977

HAL is a multi-disciplinary open access archive for the deposit and dissemination of scientific research documents, whether they are published or not. The documents may come from teaching and research institutions in France or abroad, or from public or private research centers.
L'archive ouverte pluridisciplinaire HAL, est destinée au dépôt et à la diffusion de documents scientifiques de niveau recherche, publiés ou non, émanant des établissements d'enseignement et de recherche français ou étrangers, des laboratoires publics ou privés. 


\title{
SHORT RANGE ORDER IN SUPERIONIC CONDUCTORS
}

\author{
J. P. BOILOT, A. KAHN, J. THERY
}

Chimie Appliquée de 1'Etat Solide, rue P.-et-M.-Curie, 75005 Paris, France

\section{G. COLLIN and R. COMES}

Physique des Solides, Université Paris-Sud, 91405 Orsay, France

Résumé. - Les superconducteurs ioniques ont de très intéressantes applications dans de nouveaux types de batteries solides.

Nous présentons les résultats obtenus par diffraction et par diffusion des rayons $\mathrm{X}$ sur certains de ces matériaux et en relation avec les propriétés :

- la diffraction des rayons $\mathrm{X}$ est une méthode très efficace pour la détermination de la répartition des ions sur les différents sites disponibles du réseau cristallin et de l'évolution de cette répartition avec la température, les conditions de préparation...,

- la diffusion des rayons $\mathrm{X}$ fournit des informations sur l'organisation réelle des ions à l'échelle de quelques mailles et donc en principe une information directe sur les interactions entre ions.

Tous les superconducteurs ioniques possèdent des structures avec des défauts étendus qui sont à l'origine de leur très haute conduction. Le plus intéressant est l'alumine bêta avec des propriétés exceptionnelles. Dans ce cas le désordre est essentiellement bidimensionnel.

Les déterminations structurales obtenues par diffraction indiquent une répartition des ions de conduction sur 3 types de sites, B-R, m-O, aB-R - avec des différences importantes entre $\mathrm{Na}^{+}$, $\mathrm{K}^{+}, \mathrm{Tl}^{+}$et $\mathrm{Ag}^{+}$, et également la présence d'un défaut de Frenkel, mis en évidence par Roth et al., avec de l'oxygène interstitiel fournissant le mécanisme de compensation pour la non-stœechiométrie.

La diffusion des rayons $\mathrm{X}$ indique plusieurs types d'ordres locaux - un pour les ions $\mathrm{Na}^{+}$, un pour les ions $\mathrm{Ag}^{+}$qui, à haute température, sont dans un état quasi liquide, et un autre pour les ions $\mathrm{K}^{+}$ et $\mathrm{Tl}^{+}$, proche de l'ordre local mis en évidence pour l'alumine bêta et l'argent à basse température.

Abstract. - Superionic conductors have potential application in new types of batteries, fuel cells and sensors.

Our purpose is to present the results obtained by both classical X-ray diffraction and X-ray diffuse scattering techniques on some of them and to show what kind of information could be expected in relation with properties :

- X-ray diffraction is a very powerful method for the study of ion repartition on the various available sites of crystal lattice and of changes of this repartition with respect to temperature, preparation conditions...

- X-ray diffuse scattering provides insight on the real local organization of ions at a scale of a few unit cells and in principle the most direct information about ion-ion interactions.

All superionic conductors exhibit extended defects structure which are responsible of their high ionic conductivity. The most important of them is beta alumina with very attractive properties. In this case, the disorder is essentially two dimensional.

Structural determinations are deduced from Bragg diffraction show a repartition of conduction lons on three kinds of sites B-R, m-O, aB-R, with important differences between $\mathrm{Na}^{+}, \mathrm{K}^{+}, \mathrm{Tl}^{+}$ and $\mathrm{Ag}^{+}$. and also the occurrence of Frenkel defects, as seen by Roth and interstitial oxygen prouding the compensation mechanism for non-stolchiometry.

Diffuse X-ray scattering indicates several types of local orders : one for $\mathrm{Na}^{+}$ions one for $\mathrm{Ag}^{+}$ ions which, at high temperature, are in a two dimensional quasi-liquid state and another for $\mathrm{K}$. and $\mathrm{Tl}^{+}$ions closely related to the local arrangement in low temperature silver beta alumina.

Introduction. - In the past few years, superionic conductors have attracted considerable current interest, largely due to their potential application in solid batteries. We present here some results concerning these materials studied by $\mathrm{X}$-rays diffraction techniques.
In general, superionic conductors are materials in which there are several available sites for one conducting ion and consequently it leads to empty or weakly occupied sites, displacements, jumps and therefore, disorder. In the case of ordinary ionic conductors $\left(\sigma=10^{-20}(\Omega \mathrm{cm})^{-1}\right.$ for $\mathrm{NaCl}$ for instance), the 
electrical conductivity arises from the lattice imperfections (impurities, vacancies, interstitials...) and is proportional to the defect concentration of the lattice. Nevertheless, in a pure crystal, the defect concentration always remains very weak. On the contrary. in superionic conductors, this defect concentration is in the same range as the occupied site concentration.

There are several kinds of superionic conductors :

- isotropic cationic conductors whose type is $\alpha$-AgI, with a statistical distribution of the $4 \mathrm{Ag}^{+}$ions over 42 sites in the unit cell. Other superionic conductors of this type are $\mathrm{RbAgI}_{5}, \mathrm{HgAg}_{2} \mathrm{I}_{4}, \ldots$;

- two-dimensional anisotropic cationic conductors with the beta alumina type compounds $11 \mathrm{Al}_{2} \mathrm{O}_{3}-\left(\mathrm{B}_{2} \mathrm{O}\right)_{x}$, the conducting ions being localized in non intercommunicating planes separated by spinel blocks;

- one dimensional anisotropic cationic conductors which are materials with tungsten bronze or hollandite type and the ionic motion occurs along the channels of the tetragonal lattice;

- organo-metallic cationic conductors, in general with copper ;

- anionic superconductors, fluorides $\mathrm{CaF}_{2}, \mathrm{PbF}_{2}$ or binary fluorides with a mobility of the $\mathrm{F}^{-}$ions or of the $\mathrm{O}^{2-}$ ions of $\left(\mathrm{ZrO}_{2}: \mathrm{CaO}\right)$ at high temperature.

Some of these materials can be used for electrical energy production, especially $\mathrm{Na}$ beta alumina in the electrochemical system : $\mathrm{Na}-\mathrm{Na} \beta$ alumina-S with a theoretical massic energy 20 times higher than the usual lead accumulator. It is the reason of this sharp development of many studies concerning superionic conductors.

X-rays diffraction. - In the case of superionic conductors, X-rays diffraction studies supply two kinds of information :

- Bragg diffraction and crystal structure analysis provides both the total amount of mobile ions in the unit cell and also the average repartition of these ions between the different sites of the lattice;

- X-rays diffuse scattering provides direct informations about the actual organization of the conducting ions at a local scale and about the short range ion-ion correlations.

Indeed any deviation from the perfect periodic structure, which gives rise to the Bragg diffraction, produces an extra-scattering at general positions in reciprocal space. Generally, the scattered intensity is proportional to $I_{D}$ given by :

$$
I_{\mathrm{D}}=\langle F-\langle F\rangle\rangle^{2} \exp -2 M
$$

where $F$ is the local structure factor, $\langle F\rangle$ the average structure factor and $M$ the Debye-Waller factor.

The technique used for collecting intensities (fixed film, fixed crystal) is shown in figure $1 a$. The film corresponds then, point by point, to all general
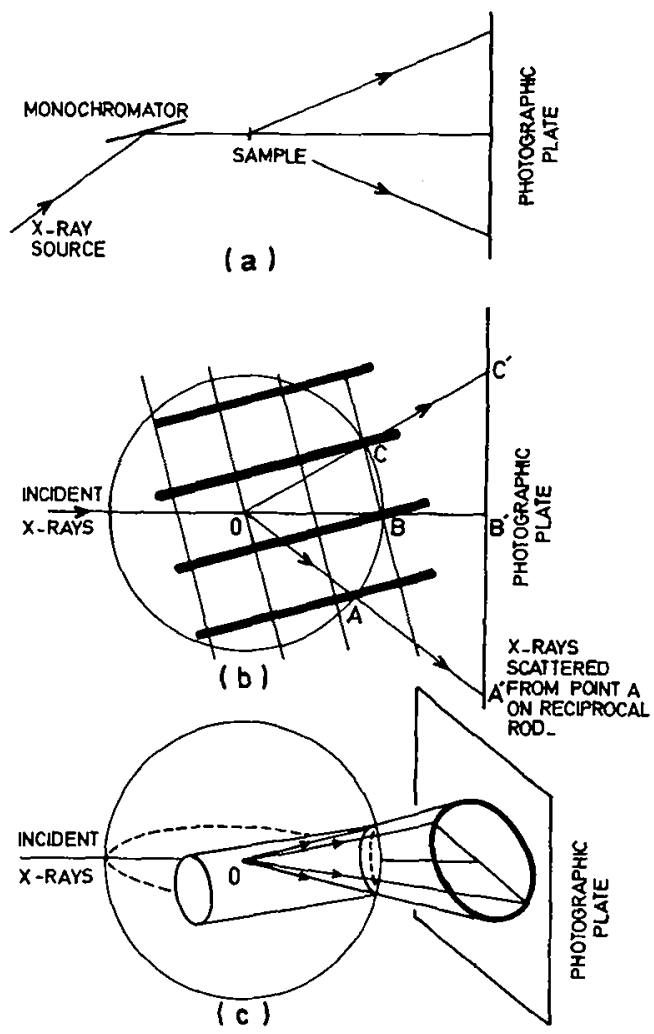

FIG. 1. - a) Schematic set up of the fixed crystal fixed film X-ray diffuse scattering technique. b) Corresponding view of a vertical section of reciprocal space, showing the intersection of a lattice displaying intensity localized on rods, with the Ewald sphere and the resulting scattered beams. $c$ ) Corresponding view in reciprocal space in the case of a two-dimensional liquid giving rise to intensity localized on a cylinder. When the 2-d liquid is not perpendicular to the incident beam, the resulting halo is elongated.

positions in reciprocal space which simultaneously satisfy the relations :

$$
\mathbf{Q}=h \mathbf{a}^{*}+k \mathbf{b}^{*}+l \mathbf{c}^{*}=2 \pi\left(\mathbf{S}-\mathbf{S}_{0}\right) / \lambda
$$

where $\mathbf{a}^{*}, \mathbf{b}^{*}, \mathbf{c}^{*}$ are the reciprocal lattice parameters, $\mathbf{S}$ is the unit vector of each scattered beam, $\mathbf{S}_{0}$ the unit vector of the incident beam and $\lambda$ is the wavelength. In this case, $h, k, l$, are not restricted to integer values as for usual Bragg diffraction. Figure $1 b$ shows a vertical section containing the incident beam, the locus of the points $2\left(\mathbf{S}-\mathbf{S}_{0}\right) / \lambda$ (Ewald sphere), a reciprocai space corresponding to intensity located along reciprocal rods as expected from two-dimensional local order. Figure $1 c$ shows a similar construction in the case of a two-dimensional liquid which corresponds in reciprocal space to an intensity maximum localized on a cylinder.

Beta alumina. - The beta alumina materials are a family of compounds with general formula $11 \mathrm{Al}_{2} \mathrm{O}_{3}$ $\mathrm{B}_{x} \mathrm{O}$. The unit cell is hexagonal (space group $\mathrm{P} 6_{3} / \mathrm{mmc}$ ) (figure 2). The outstanding feature is the stacking of close packed spinel blocks separated by mirror planes 


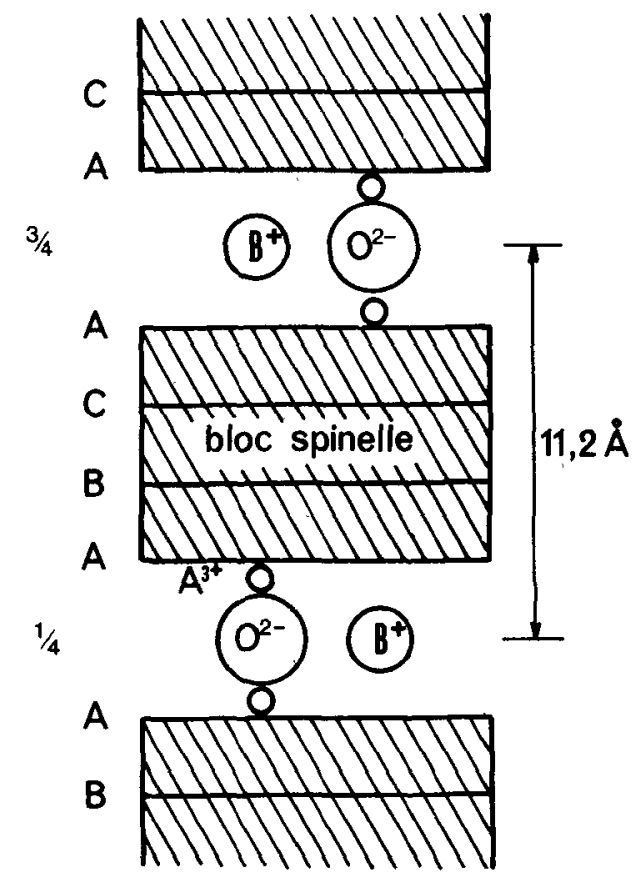

FIG. 2. - Schematic representation of the $\beta$ alumina structure.

perpendicular to the $c$ axis and containing $\mathrm{B}^{+}$ ions. These mirror planes, 2 per unit cell, form twodimensional lattices in which the ionic conduction takes place.

The corresponding two-dimensional unit cell is hexagonal, p31m, with 3 kinds of cationic sites (figure 3):

- The Beevers-Ross site (B-R) which is the most occupied one $(>2 / 3)$;

- The mid-oxygen site $(\mathrm{m}-\mathrm{O})$ less occupied than B-R sites;

- The anti-Beevers-Ross sites (a B-R) which are generally weakly occupied except in the special case of silver beta alumina.

The anionic site, always fully occupied by an oxygen ion. In general, the different sites are shifted with respect to their regular positions.

Only Na $\beta$ alumina can be obtained by direct synthesis and all the other compounds are prepared by ion exchange in molten salt (generally nitrates).

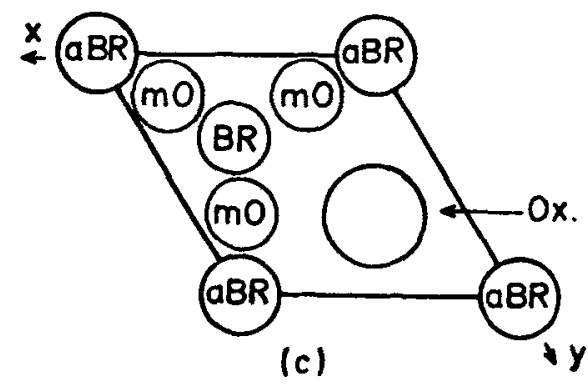

FIG. 3. - Simplified site model used for the determination of the local order with the conventional site denomination B.V. = Beevers-Ross, a B.V. = anti-Beevers, $\mathrm{mO}=$ mid-Oxygen

Crystal structure analysis of $\beta$ alumina. - Crystal structure analysis results are given in the table $I$ for a series of such $\beta$ alumina compounds :

(i) two compounds labelled $\mathrm{K}_{(2)}$ and $\mathrm{Tl}_{(2)}$ are quite similar [4] with the same kind of ion repartition between the different cationic sites. The case of silver beta alumina [5] looks somewhat different but, in fact, there is only an inversion between the $\mathrm{m}-\mathrm{O}$ and a B-R sites. And we shall see later that, taking into account this inversion, we find roughly the same results than for potassium and thallium beta alumina;

(ii) for the compound labelled $\mathrm{Tl}_{(1)}$ (Table II), we are dealing with a partial substitution of $\mathrm{Na}$ by $\mathrm{Tl}$, the amount of $\mathrm{Tl}$ ions in the cell is only about one half of the usual value in beta alumina. The substitution occurs only on the B-R site which, then, takes a preferential part in the substitution mechanism as in the ion diffusion;

(iii) the difference between $\mathrm{K}_{(1)}$ and $\mathrm{K}_{(2)}$ arises from a difference in the preparation conditions. Indeed $K_{(1)}$ corresponds to the result given by Dernier and Remeika [3] for a crystal prepared by flux, that is to say at much lower temperature $\left(1300^{\circ} \mathrm{C}\right)$ than our own crystal $\left(K_{(2)}\right)$ prepared from the melt. We observe that this difference between the preparation temperatures gives rise to an important difference in the cation repartition;

(iiii) on the other hand, the results for $\mathrm{Na}_{(1)}$, a structural determination by Roth et al. [1] using neutron diffraction, and $\mathrm{Na}_{(2)}$, our own results [2] obtained

\section{TABLE I}

Occupancy factors in beta alumina compounds

$\begin{array}{cccccccc} & \mathrm{Na}_{(1)} & \mathrm{Na}_{(2)} & \mathrm{K}_{(1)} & \mathrm{K}_{(2)} & \mathrm{Tl}_{(1)} & \mathrm{Tl}_{(2)} & \mathrm{Ag} \\ \mathrm{BR} & - & - & - & - & - & - & - \\ \mathrm{m}-\mathrm{O} & 1.66 & 1.54(5) & 1.42(2) & 1.56(1) & 1.24(1) & 1.75(2) & 1.34(1) \\ \mathrm{a}-\mathrm{BR} & 0.75 & 0.97(6) & 1.22(2) & 0.75(1) & 0 & 0.51(2) & 0.34(1) \\ \text { Total } & 0.10 & 0.00(5) & 0.00 & 0.28(1) & 0 & 0.21(2) & 0.87(1) \\ & 2.51 & 2.51 & 2.64 & 2.59 & 1.24 & 2.47 & 2.55\end{array}$


TABLE II

Partially substituted thallium beta alumina. Positions and thermal parameters. The $U_{i j}\left(\AA^{2} \times 10^{4}\right)$ are given by the formula $\exp 2 \pi^{2} \sum_{i, j} U_{i j} h_{i} h_{j} a_{i}^{*} a_{j}^{*}, B$ is given in $\AA^{2} \times 10^{4}$

\begin{tabular}{|c|c|c|c|c|c|c|c|c|c|}
\hline & Position & $\begin{array}{c}\text { Number } \\
\text { per unit } \\
\text { cell }\end{array}$ & $\begin{array}{c}x .10^{4} \\
-\end{array}$ & $\begin{array}{c}z .10^{4} \\
-\end{array}$ & $\underline{U_{11}}$ & $\underline{U_{22}}$ & $U_{33}$ & $\underline{U_{13}}$ & $\stackrel{B}{-}$ \\
\hline All & $12 \mathrm{k}$ & 12 & $8326(3)$ & $1049(1)$ & $109(7)$ & $112(10)$ & $156(8)$ & $-1(8)$ & \\
\hline Al2 & $4 \mathrm{f}$ & 4 & 3333 & $145(2)$ & $104(10)$ & $U_{11}$ & $142(12)$ & 0 & \\
\hline Al3 & $4 f$ & 4 & 3333 & $1753(2)$ & $119(10)$ & $U_{11}$ & $102(12)$ & 0 & \\
\hline Al4 & $2 a$ & 2 & 0 & 0 & $94(14)$ & $U_{11}$ & $168(15)$ & 0 & \\
\hline $\mathrm{O} 1$ & $12 \mathrm{k}$ & 12 & $1581(6)$ & $500(2)$ & $90(14)$ & $71(20)$ & $114(18)$ & $8(10)$ & \\
\hline $\mathrm{O} 2$ & $12 \mathrm{k}$ & 12 & $5020(6)$ & $1443(2)$ & $110(15)$ & $119(20)$ & $102(20)$ & $8(11)$ & \\
\hline $\mathrm{O} 3$ & $4 f$ & 4 & 6666 & $556(4)$ & $96(22)$ & $U_{11}$ & $169(45)$ & 0 & \\
\hline $\mathrm{O} 4$ & $4 e$ & 4 & 0 & $1407(4)$ & $57(20)$ & $U_{11}$ & $122(42)$ & 0 & \\
\hline O5 & $2 c$ & 2 & 3333 & 2500 & $551(100)$ & $U_{11}$ & 291(110) & 0 & \\
\hline T11 & $6 \mathrm{~h}$ & $1.24(1)$ & $6708(11)$ & 2500 & $257(10)$ & $622(58)$ & $165(6)$ & 0 & \\
\hline $\mathrm{T} 12$ & $6 \mathrm{~h}$ & $0.12(2)\left(^{*}\right)$ & $8920(53)$ & 2500 & & & & & $376(130)$ \\
\hline $\mathrm{Tl} 3$ & $6 \mathrm{~h}$ & $0.11(2)\left(^{*}\right)$ & $9561(40)$ & 2500 & & & & & $258(10)$ \\
\hline
\end{tabular}

$\left(^{*}\right)$ These two sites m-O and aB-R are occupied mainly by Na ions with a few T1 ions. Refinements performed with 493.

with X-rays, are in fair agreement, at least in the limit of standard deviations. The only difference arises in the occupancy of a B-R site which Roth et al. found slightly occupied and which we find completely empty.

Looking more closely at the results of refinement. another phenomenon can be observed : the thermal parameters are much higher for $\mathrm{Na}$ beta alumina than for all the other beta alumina compounds. As a matter of fact rather normal values are found for the temperature factors in $\mathrm{K}, \mathrm{Tl}, \mathrm{Ag}, \mathrm{Rb} .$. beta alumina anisotropic of course and larger in the conduction plane than in the direction of spinel blocks - but nothing exceptional for superionic conductors. On the contrary, in $\mathrm{Na}$ beta alumina, the corresponding values are considerably higher. This is a strong evidence for important displacements of $\mathrm{Na}^{+}$ions from their average positions. And indeed we will find for $\mathrm{Na}$ beta alumina an entirely different behaviour with respect to the other materials.

Another problem is : what about stoichiometry? The actual formula of beta alumina compounds is indeed $11 \mathrm{Al}_{2} \mathrm{O}_{3}-\mathrm{B}_{x} \mathrm{O}$ with $x \sim 2.5$, this means an excers of positive charges, and raises the question of the existing compensation mechanism.

An answer was first given by Roth et al. [1] who showed up the occurrence of a noticeable Frenkel defect. In the spinel blocks, on both sides of the $\mathrm{m}-\mathrm{O}$ site, stands an $\mathrm{Al}$ ion in an octahedral site. And between this $\mathrm{Al}$ ion and the $\mathrm{m}-\mathrm{O}$ site, there is an interstitial site, normaly empty, but which Roth et al. found slightly occupied (figure 4). We noted the same result in $\mathrm{Na}$ and $\mathrm{K}$ beta alumina with an exact compensation between the occupancy of this interstitial site and the vacancy on the octahedral Al site.

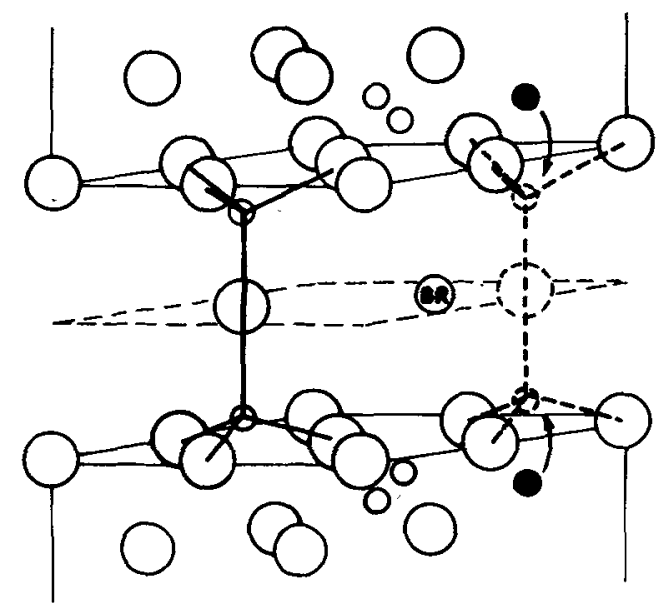

FIG. 4. - Frenkel defect in $\beta$ alumina.

But the interstitial site, in order to form a tetrahedron (a normal coordinence for $\mathrm{Al}^{3+}$ ion) must be completed with the $\mathrm{m}-\mathrm{O}$ site itself. That means. excluding both empty site and Al-K or Al-Na bounds. that one has to assume an occupancy of the $m-O$ itte by interstitial oxygen. The compensation mechanism for non-stoichiometry in beta alumina would be provided by this interstitial oxygen stabilized by the Frenkel defect.

X-rays diffuse scattering results. - From the sizes of the diffuse reflections, one can deduce the sizes of the ordered regions in our compounds. At low temperature, these sizes are found to be around $40 \AA$ except for sodium beta alumina for which we found a size of about $20 \AA$. These sizes slightly decrease 
with increasing temperature; in the case of $\operatorname{Ag} \beta$ alumina, this decrease is much more important and around $400 \mathrm{~K}$, the measured value is about $10 \AA$.

We shall begin by the simplest case : $\mathrm{Tl}_{1} \beta$ alumina. The photographic pattern (figure 5) indicates a two dimensional order (the diffuse spots arise from the intersection of rods with the Ewald sphere). They are localized on the spots on the positions of the Bragg spots of the average lattice. This pattern can be interpreted with a model of two types of regions : one type with $1 \mathrm{Tl}$ ion by cell (on B-R site) and another type without $\mathrm{Tl}$ ion. With this model, we were able to account for the positions and intensities of the diffuse reflections. It means that we get, not only a preferential substitution of $\mathrm{Tl}$ ions on B-R sites, but also an aggregation of these $\mathrm{Tl}$ ions in extended regions rather than a random distribution over the whole conduction plane.

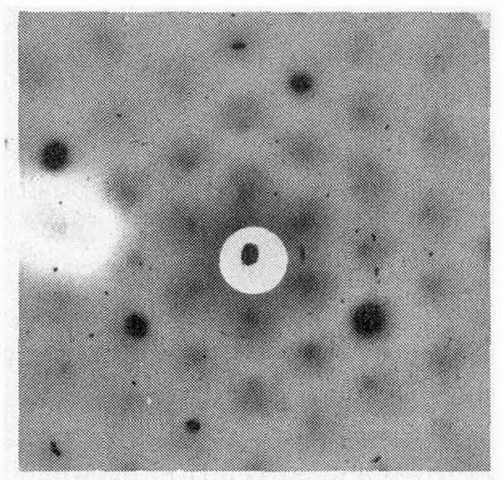

FIG. 5. - X-ray pattern from $\mathrm{Tl}_{(1)} \beta$ alumina at $300 \mathrm{~K}$.

As expected from the average structure analysis, diffuse scaltering results for $\mathrm{K}_{2}$ and $\mathrm{Tl}_{2}$ (figures 6 and 7) are quite similar. The photographic patterns show again a two-dimensional order too, but the diffuse spots are no longer localized on the positions of the main lattice and they define an hexagonal diffuse superstructure cell with a lattice constant $a \sqrt{3}$ ( $a$ lattice constant of $\beta$ alumina). The intensities of the diffuse reflections are well accounted with a model composed including several kinds of cells :

- one with $3 \mathrm{~K}$ or $\mathrm{Tl}$ ions by superstructure cell on $\mathrm{BR}$ site,

- two others with $3 \mathrm{~m}-\mathrm{O}$ or 3 aB-R sites occupied around the origin of the superstructure cell and $2 \mathrm{~K}$ or $\mathrm{Tl}$ ions on $\mathrm{B}-\mathrm{R}$ sites,

- in the case of $\mathrm{K} \beta$ alumina, to account for the intensities, we are led to introduce another kind of hexagonal superstructure cell $2 a \sqrt{3}$ (but $a \sqrt{3}$ on an average) with an occupancy of only $2 \mathrm{~m}-\mathrm{O}$ sites for some groups of $3 \mathrm{~m}-\mathrm{O}$ sites.

In both cases, the amount of each kind of cell is adjusted in such a way that the whole model is in agreement with the values of the occupancy factors deduced from the structure analysis refinements.
The results for low temperature silver beta alumina (figure 8) were previously given by Boilot et al. [6] who proposed a model built with two kinds of $a \sqrt{3}$ superstructure cells in which the three fold

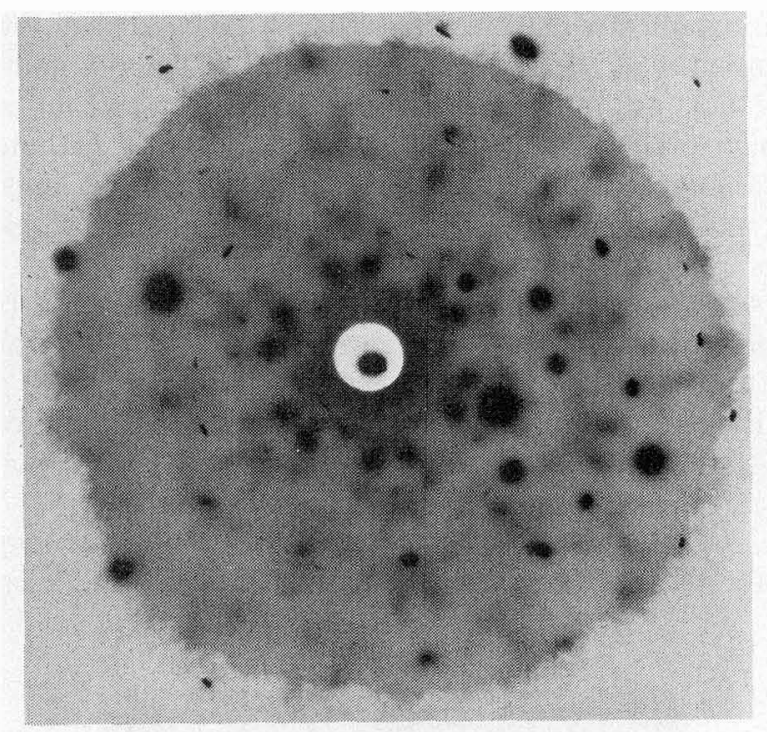

FIG. 6. - X-ray pattern from $\mathrm{K}_{(2)} \beta$ alumina at $300 \mathrm{~K}$.

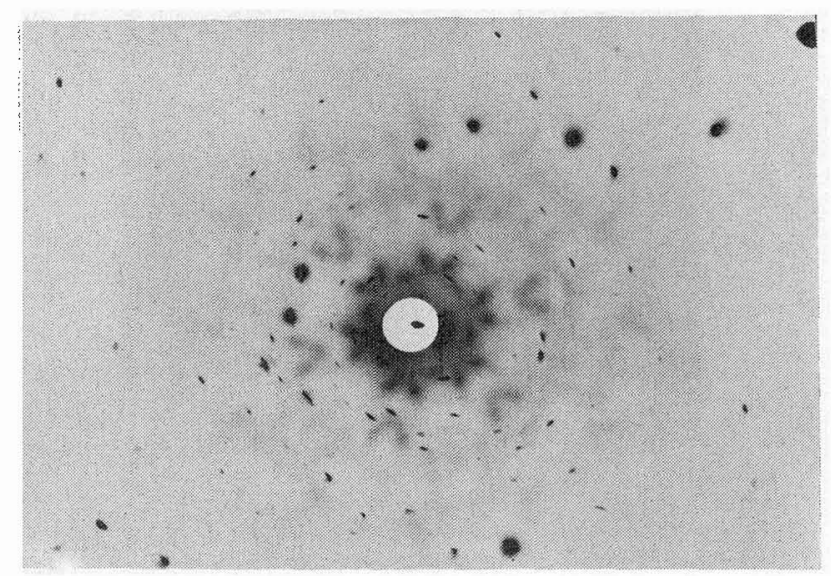

FIG. 7. $-\mathrm{X}$-ray pattern from $\mathrm{Tl}_{(2)} \beta$ alumina at $300 \mathrm{~K}$.

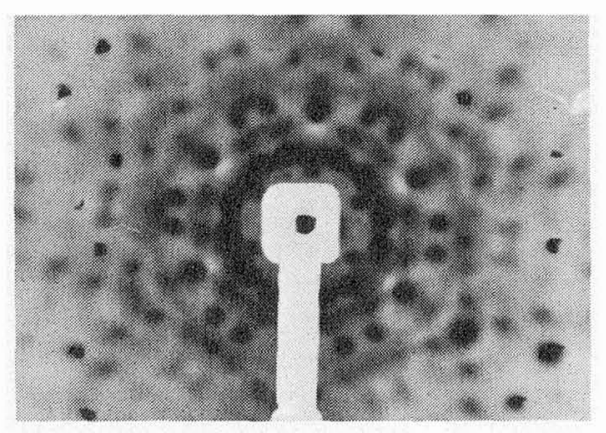

Fic. 8. - X-ray pattern from $\mathrm{Ag} \beta$ alumina at $20 \mathrm{~K}$. 
occupancy of $\mathrm{m}-\mathrm{O}$ or B-R sites around the origin was also found.

For sodium beta alumina, the diffuse scattering patterns (figure 9) are quite different from the other ones. One can again find diffuse reflections which lead to superstructure cell - trigonal $2 a \sqrt{3}$ - but important streaks are also present especially at low temperature. We are able to account for the main part of such an intensity distribution with a model in which $6 \mathrm{Na}$ ions are localized on $\mathrm{m}-\mathrm{O}$ sites around an empty aB-R site. In this case, however, we must introduce local displacements of the conducting ions from their average positions.

Another result is striking : the case of silver beta alumina at high temperature. Around $800 \mathrm{~K}$, the patterns display a diffuse halo (figure 10). Such a halo recalls the scattering characteristic of a liquid or an amorphous substance. It is a two-dimensional quass-liquid state. As shown by Bollot et al. [6]. it means that, at these high temperatures, we are dealing not only with fluctuations in the sites occupancies,

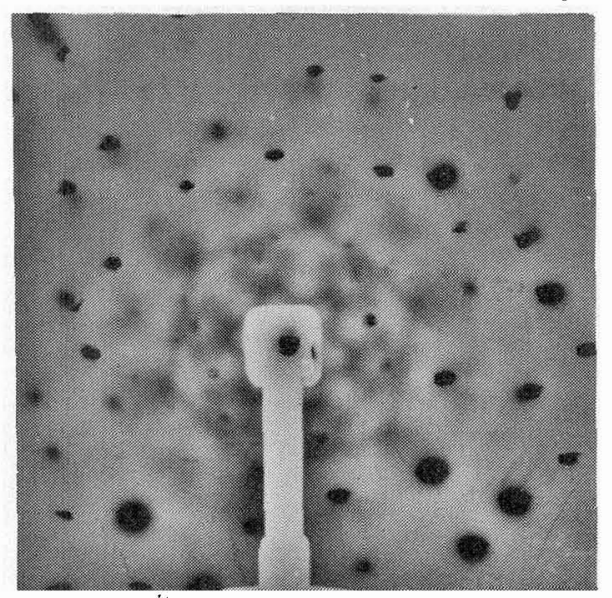

Fig. 9. - X-ray pattern from $\mathrm{Na} \beta$ alumina at $300 \mathrm{~K}$.

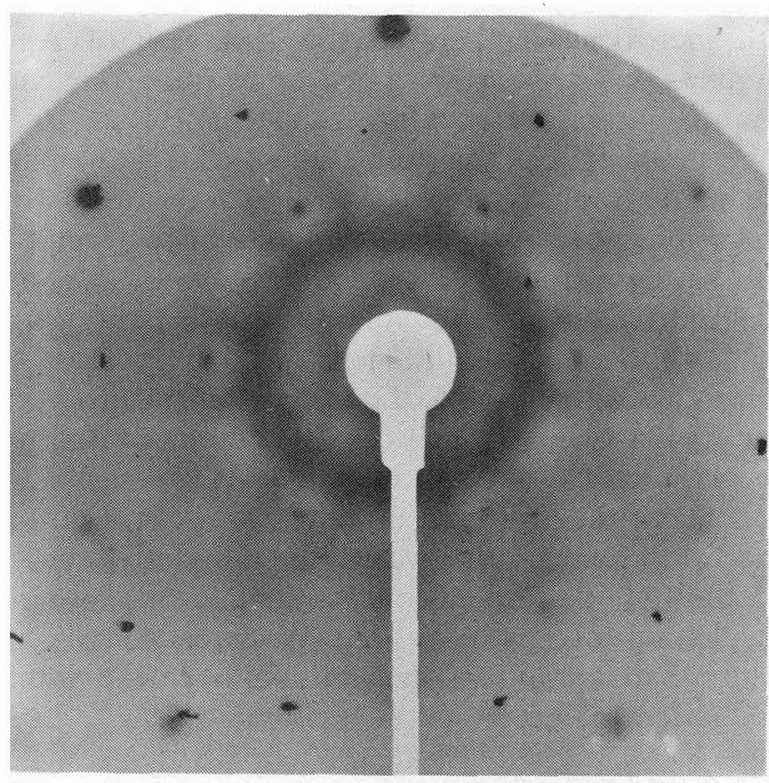

Fig. 10. - X-ray pattern from $\mathrm{Ag} \beta$ alumina at $750 \mathrm{~K}$.

but also with fluctuations in the sites positions themselves which lead to this quasi-liquid state.

Conclusion. - In this paper, we have shown the advantage of using $\mathrm{X}$-ray scattering methods, for the investigation of the local arrangements of the conducting ions in superionic conductors. In all cases, these studies have shown a clear relation between the degree of order in these compounds and their other physical properties, namely their ionic conduction.

$\mathrm{X}$-rays of course are however unable to distinguish static from dynamical effects, this is the task of neutron techniques. What we have called above short range order should more exactly be called spatial correlations in order to underline explicitly their possible dynamical charàcter.

\section{References}

[1] Roth, W. L., Reidinger, F., Laplaca, S., Proceeding of the International Conference on Superionic conductors, Schenectady, New York (1976) Ed. by Mahan and Roth (Plenum press).

[2] Boilor, J. P., Collin, G., Colomban, Ph., Thery, J., Comes, R., Congrès de la Société Française de Physique Colloque : «Phénomènes de transport dans les Solides 》, Poitiers, 27 juin 1977.
[3] Dernier, P. D., Remeika, J. P., J. Solid State Chem. 17 (1976) 245.

[4] Collin, G., Boilot, J. P., Kahn, A., Thery, J., Comes, R., to be published in J. Solid State Chem., August 1977.

[5] Roth, W. L., J. Solid State Chem. 4 (1972) 60.

[6] Bollot, J. P., Thery, J., Collongues, R., Comes, R., GuiNIER, A., Acta Crystallogr. 9 (1976) 1691. 